\title{
Analysis of Factors Affecting Behavior of the Implementation of Health Protocols to Prevent Corona Virus Disease 2019 (Covid-19) in the Work Area of Ngoro Public Health Center Mojokerto Regency
}

\author{
Sunyoto $^{1}$, Nurwijayanti ${ }^{2}$ \\ ${ }^{1}$ Ngoro Public Health Center \\ ${ }^{2}$ Master Program of Public \\ Health, Institute of Health \\ Sciences Strada Indonesia \\ Email : \\ sunyotocen27@yahoo.com
}

Received : October $4^{\text {nd }} 2021$

Accepted : October $15^{\text {rd } 2021}$

Published : November $27^{\text {th }} 2021$

\begin{abstract}
The community has an important role in breaking the chain of Covid-19 transmission so as not to cause new sources of transmission / clusters in places where people move, interact between people and gather many people. The role of the community in being able to break the chain of Covid-19 transmission (risk of contracting and transmitting) must be carried out by implementing health protocols. This study aims to determine the influence of the factors of knowledge, attitudes, availability of facilities and infrastructure and support for the behavior of implementing health protocols in an effort to prevent Covid-19 in the work area of Ngoro Public Health Center Mojokerto Regency. This research is an analytic survey research with a cross sectional approach. The study population was the population in Ngoro Public Health Center area. The sampling technique used is a simple sampling technique with a total sample size of 348 people. Retrieval of data using a questionnaire. Data analysis using multiple linear regression analysis. The results of this study indicate that the knowledge factor, attitude factor, and support factor partially influence the behavior of implementing health protocols. Attitude factor is the dominant factor affecting the behavior of implementing health protocols. While the knowledge factor, attitude factor, availability of health protocol facilities as well as support factors simultaneously influence the behavior of implementing health protocols in an effort to prevent Covid-19 in the work area of Ngoro Public Health Center Mojokerto Regency. To improve the behavior of implementing health protocols in the community, it is necessary to carry out activities of counseling, education, socialization, dissemination of information and supported by policies and regulations. Examples from health workers and community leaders are also needed in order to become a reference for the community.
\end{abstract}

Keywords: Knowledge, attitudes, health protocol facilities, support, behavior

Copyright @ 2021 IIK STRADA Indonesia All right reserved.

This is an open-acces article distributed under the terms of the Creative Commons AttributionShareAlike 4.0 International License. 


\section{INTRODUCTION}

Coronavirus $(\mathrm{CoV})$, which is a large family of viruses that causes illness ranging from mild to severe symptoms. There are at least two types of coronavirus that are known to cause diseases that can cause severe symptoms such as Middle East Respiratory Syndrome (MERS) and Severe Acute Respiratory Syndrome (SARS). Coronavirus Disease 2019 (Covid-19) is a new type of virus that has never been previously identified in humans. Corona viruses are zoonotic (transmitted between animals and humans). Research states that SARS is transmitted from civet cats to humans and MERS from camels to humans. Several coronaviruses are known to circulate in animals but have not been proven to infect humans (Ministry of Health, 2020).

WHO reports that limited human-to-human transmission (to close contact and health workers) has been confirmed in China and other countries. Based on previous MERS and SARS incidents, human-to-human transmission occurred through droplets, contact and contaminated objects, so the transmission of Covid-19 is estimated to be the same. Standard recommendations for preventing the spread of infection are regular hand washing, coughing and sneezing, avoiding direct contact with livestock and wild animals and avoiding close contact with anyone showing symptoms of respiratory illness such as coughing and sneezing. In addition, implementing Infection Prevention and Control (PPI) while in health facilities, especially emergency units (Ministry of Health, 2020).

As of June 28, 2020, WHO reported a total of 9,782,197 confirmed cases with 494,421 deaths (CFR 5.05\%) with cases reported in 216 countries / regions (WHO, 2020). As of June 28, 2020, Indonesia has reported 54,010 confirmed cases of Covid-19 with 2,754 deaths. Meanwhile, East Java Province reported 11,508 confirmed cases with 831 deaths. Meanwhile, Mojokerto Regency on June 28, 2020, reported 174 confirmed cases of Covid-19, with 13 deaths. In Ngoro Public Health Center area which covers 13 villages as of September 30, 2020, reported 58 confirmed cases of Covid-19.

Based on scientific evidence, Covid-19 can be transmitted from human to human through coughing / sneezing droplets, not through the air. The people most at risk of contracting this disease are people who have close contact with Covid-19 patients, including those who treat Covid-19 patients. Standard recommendations for preventing the spread of infection are regular hand washing with soap and clean water, practicing coughing and sneezing, avoiding direct contact with livestock and wild animals and avoiding close contact with anyone showing respiratory symptoms such as coughing and sneezing. In addition, implementing Infection Prevention and Control (PPI) while in health facilities, especially the emergency department. (Ministry of Health, 2020).

The community has an important role in breaking the chain of transmission of Covid-19 so as not to cause new sources of transmission/clusters in places where the movement of people, interaction between humans and large gatherings of people occurs. The community must be able to carry out activities again in the Covid-19 pandemic situation by adapting to new habits that are healthier, cleaner, and more obedient, which are carried out by all components in the community and empowering all available resources. The role of the community in being able to break the chain of transmission of Covid-19 (risk of contracting and transmitting) must be carried out by implementing health protocols (KMK RI, HK.01.07 / MENKES / 382/2020). To prevent transmission of Covid-19, the public is obliged to apply health protocols. However, in the work area of Ngoro Public Health Center there are still people who have not implemented the health protocol because there are still people who lack knowledge regarding the dangers of spreading the Corona virus. Therefore it is necessary to conduct research to determine the factors that influence people's behavior in implementing health protocols.

\section{MATERIALS AND METHODS}

Based on the information passed the ethical number test : 2225/KEPK/XII/2020 Health Research Ethics Committee Institute of Health Science STRADA Indonesia in the effort to protect the rights and welfare of research subjects of health, has reviewed carefully the protocol entitled : "Analysis of Factors Affecting Behavior of The Implementation of Health Protocols to Prevent Corona Virus Disease 2019

(Covid-19) in The Work Area of Ngoro Public Health Center Mojokerto Regency" and approved the above mentioned protocol.

This research is an analytic survey research with a cross sectional approach. The study population was the population in Ngoro Public Health Center area. The sampling technique used is simple random 
sampling, this technique is a sample taken in such a way that each research unit or elementary unit of the population has the same opportunity to be selected as a sample (Muhith, 2011). The total sample was 348 people. The research was conducted by taking the necessary data using a questionnaire that had been prepared previously. The data collection process is carried out at one time for all variables. The dependent variable in this study is the behavior of the implementation of health protocols. While the independent variables are knowledge, attitude, availability of health protocol facilities, and support factors. The data that has been collected will be analyzed using multiple linear regression analysis.

\section{RESULTS}

Table 1 Distribution Frequency Characteristics of Respondents in The Work Area of Ngoro Public Health Center Mojokerto Regency, 2020

\begin{tabular}{c|l|c|c}
\hline No. & Respondent Age & $(\mathrm{f})$ & $(\%)$ \\
\hline 1. & 26 years & 31 & 8,90 \\
& $26-40$ years & 174 & 50,00 \\
& $41-55$ years & 4 & 33,9 \\
& $56-70$ years & 24 & 6,9 \\
& $>85$ years & 1 & 0,30 \\
& Total & 348 & 100,00 \\
\hline 2. & Respondent Sex & 174 & 50,00 \\
\hline & Male & 110 & 31,60 \\
& Female & 238 & 68,40 \\
& Total & 348 & 100,00 \\
\hline 3. & Respondent Graduate & & 1,40 \\
& No School & 5 & 9,20 \\
& Elementary School & 32 & 16,70 \\
& Junior High School & 58 & 59,50 \\
& Senior High School & 207 & 13,20 \\
& College & 46 & 100,00 \\
\hline & Total & 348 & \\
\hline 4. & Respondent Occupation & & 35,30 \\
& Does Not Work & 123 & 19,30 \\
& Entrepreneur & 67 & 8,90 \\
& The Farmer & 31 & 28,70 \\
& Private Employees & 100 & 7,80 \\
& PNS/TNI/Polri & 27 & 100,00 \\
\hline
\end{tabular}

Source : Primary Data (2020)

Based on the research data in table 1, it is known that out of 348 respondents, the characteristics of respondents, seen from the age of respondents, were mostly respondents with the age of 26-40 years with a number of 174 people $(50,00 \%)$, mostly respondents sere female with a number of 238 people $(68,40 \%)$, most of the respondents were high school graduates with a number 207 people $(59,50 \%)$, most of the respondents do not work with a number 123 people $(35,30 \%)$. 
Table 2 Cross Tabulation between Characteristics of Respondents and Behavior of Health Protocol Implementation in The Work Area of Ngoro Public Health Center Mojokerto Regency,2020

\begin{tabular}{c|l|c|c|c|c|c|c|c|c}
\hline \multirow{2}{*}{ No. Characteristics of } & \multirow{2}{*}{\begin{tabular}{c} 
Respondents \\
\cline { 3 - 10 }
\end{tabular}} & & \multicolumn{6}{c}{ Gehavior of Health Protocol Implementation } \\
\cline { 3 - 10 } & & (f) & $(\%)$ & (f) & $(\%)$ & (f) & $(\%)$ & (f) & $(\%)$ \\
\hline 1. & Knowledge & & & & & & & & \\
\hline & Good & 295 & 87,54 & 39 & 11,57 & 3 & 0,89 & 337 & 100,00 \\
& Enough & 0 & 0,00 & 11 & 100,00 & 0 & 0,00 & 11 & 100,00 \\
& Total & 295 & 84,77 & 50 & 14,37 & 3 & 0,86 & 348 & 100,00 \\
\hline 2. & Attitude & & & & & & & & \\
\hline & Want to do & 283 & 98,61 & 4 & 1,39 & 1 & 0,35 & 287 & 100,00 \\
& Do not want to do & 12 & 20,69 & 46 & 79,31 & 2 & 3,45 & 58 & 100,00 \\
& Total & 295 & 85,51 & 50 & 14,49 & 3 & 0,87 & 345 & 100,00 \\
\hline 3. & Availability of Health & & & & & & & & \\
& Protocol Facilities & & & & & & & & \\
\hline & Complete & 235 & 86,08 & 36 & 13,19 & 2 & 0,73 & 273 & 100,00 \\
& Incomplete & 60 & 80,00 & 14 & 18,67 & 1 & 1,33 & 75 & 100,00 \\
& Total & 295 & 84,77 & 50 & 14,37 & 3 & 0,86 & 348 & 100,00 \\
\hline 4. & Support & & & & & & & & \\
\hline & Strong & 291 & 92,09 & 23 & 7,28 & 2 & 0,63 & 316 & 100,00 \\
& Weak & 4 & 12,50 & 27 & 84,38 & 1 & 3,13 & 32 & 100,00 \\
& Total & 295 & 84,77 & 50 & 14,37 & 3 & 0,86 & 348 & 100,00 \\
\hline
\end{tabular}

Source : Primary Data (2020)

Based on table 2, the results of cross tabulation between the respondent's knowledge and the behavior of implementing health protocols show that most of the respondents with good knowledge are 295 people $(87.54 \%)$ have good health protocol implementation behavior, 39 people (11.57) have poor behavior and 3 people $(0.89 \%)$ had bad behavior.

The results of cross tabulation between the respondent's attitude and the behavior of implementing the health protocol showed that most of the respondents who had the attitude of wanting to apply the health protocol as many as 283 people $(98.61 \%)$ had good health protocol implementation behavior, as many as 4 people $(1,39 \%)$ had bad behavior and as much as 1 person $(0.35 \%)$ had bad behavior.

The results of cross tabulation between the availability of health protocol facilities with the behavior of implementing health protocols show that most of the respondents who had complete health protocol facilities availability were 235 people $(86.08 \%)$ had good health protocol implementation behavior, as many as 36 people $(13.19 \%)$ had bad behavior and as many as 2 people $(0.73 \%)$ had bad behavior.

The results of cross tabulation between support for the implementation of health protocols with the behavior of implementing health protocols show that the majority of respondents who have strong support are 291 people (92.09\%) have good health protocol implementation behavior, as many as 23 people $28 \%$ ) have bad behavior and as many as 2 people $(0.63 \%)$ have bad behavior.

Table 3 Regression Analysis Test Results

\begin{tabular}{c|l|c|c|c|c|c}
\hline \multirow{2}{*}{ No. Model } & \multicolumn{2}{|c|}{$\begin{array}{c}\text { Unstandardized } \\
\text { Coefficient }\end{array}$} & $\begin{array}{c}\text { Standardized } \\
\text { Coefficient }\end{array}$ & \multirow{2}{*}{ Significance } \\
\cline { 3 - 5 } & & $\mathrm{B}$ & Std Error & Beta & & \\
\hline 1. & Knowledge & 0,189 & 0,079 & 0,85 & $-1,157$ & 0,017 \\
\hline 2. & Attitude & 0,658 & 0,040 & 0,637 & 2,396 & 0,000 \\
\hline 3. & $\begin{array}{l}\text { Availability of Facilities and } \\
\text { Infrastructures }\end{array}$ & $-0,028$ & 0,031 & $-0,030$ & 16,525 & 0,353 \\
\hline 4. & Support & 0,293 & 0,053 & 0,217 & $-0,930$ & 0,000 \\
\hline
\end{tabular}

Source : Primary Data (2020)

Based on the results of the regression analysis, the regression equation is obtained as follows: $\mathrm{Y}$ $=0.085 \mathrm{X} 1+0.637 \mathrm{X} 2+-0.30 \mathrm{X} 3+0.217 \mathrm{X} 4$. Based on the above equation, it can be explained that knowledge, attitude, and support have a positive influence on the behavior of implementing health 
protocols in an effort to prevent Corona Virus Disease (Covid-19). This means that the better these factors, the better the behavior of implementing health protocols. Meanwhile, the availability of health protocol facilities does not have a positive influence on the behavior of implementing health protocols to prevent Corona Virus Disease (Covid-19). This means that the better these factors do not contribute to the better the behavior of implementing health protocols.

Table 4 Multiple Regression Analysis Results (ANOVA)

\begin{tabular}{l|c|c|c|c|c}
\hline \multicolumn{1}{c|}{ Model } & Sum of Squares & df & Mean Square & F & Significance \\
\hline Regression & 35,160 & 4 & 8,790 & 169,103 & 0,000 \\
\hline Residual & 17,829 & 343 & 0,052 & & \\
\hline Total & 52,989 & 347 & & & \\
\hline
\end{tabular}

Source : Primary Data (2020)

The results of multiple regression analysis obtained the calculated $F$ value of 169.103 with a significance of 0.000 . Because the significance value is smaller than $0.05(\mathrm{p}<0.05)$, the hypothesis is accepted. This means that the variables of knowledge, attitude, availability of health protocol facilities and support simultaneously affect the behavior of implementing health protocols in an effort to prevent Corona Virus Disease (Covid-19).

Table 5 The Coefficient of Determination $\left(\mathrm{R}^{2}\right)$

\begin{tabular}{c|c|c|c}
\hline $\mathrm{R}$ & $\mathrm{R}$ Square & Adjusted R Square & Std. Error of The Estimate \\
\hline 0,815 & 0,664 & 0,660 & 0,228 \\
\hline
\end{tabular}

Source : Primary Data (2020)

The results of multiple regression analysis obtained the value of R Square (R2) of 0.664. This shows that the behavior of implementing health protocols in an effort to prevent Corona Virus Disease (Covid-19) is influenced by variables of knowledge, attitudes, availability of health protocol facilities and support by $66.4 \%$, while the remaining $33.6 \%$ is influenced by other factors that are not researched in this study.

Table 6 Regression Coefficient Values

\begin{tabular}{c|l|c|c}
\hline No. & \multicolumn{1}{|c|}{ Variable } & Coefficient Value & Rank \\
\hline 1. & Knowledge & 0,085 & III \\
\hline 2. & Attitude & 0,637 & I \\
\hline 3. & Availability of Health Protocol Facilities & $-0,30$ & IV \\
\hline 4. & Support & 0,217 & II \\
\hline
\end{tabular}

Source : Primary Data (2020)

The regression coefficient value table shows that the highest coefficient value in the attitude variable is 0.637 , so that the dominant variable / factor that affects the behavior of implementing health protocols to prevent Corona Virus Disease (Covid-19) is an attitude variable.

\section{DISCUSSION}

Analysis of The Relationship between Predisposing Factors (Knowledge and Attitude) on The Behavior of The Implementation of Health Protocols in Prevention of Corona Virus Disease 2019 (Covid-19) in The Work Area of Ngoro Public Health Center Mojokerto Regency

The results of the research data analysis show that the knowledge factor partially has a significant effect on the behavior of implementing health protocols to prevent Corona Virus Disease (Covid-19) in the Work Area of Ngoro Public Health Center, Mojokerto Regency. It is shown by the results of multiple regression analysis, the $t$ value is 2.396 with a significance level of 0.017 ( $p<0.05)$. This result means that the public knowledge factor has a significant effect on the behavior of implementing health protocols.

Knowledge is the result of human sensing, or the result of a person's knowing of objects through their senses (eyes, nose, ears, etc.). By itself, the time of sensing to produce knowledge is very much influenced by the intensity of attention and perception of the object. Most of a person's 
knowledge is obtained through the sense of hearing (ears), the sense of sight (eyes). According to Notoatmodjo (2010), knowledge is one of the domains of behavior.

Health knowledge includes what a person knows about ways to maintain health. The knowledge that a person must have in order to be able to apply health protocol behavior is about how Covid-19 is transmitted, how to prevent it by implementing health protocols, namely wearing masks, keeping distance and avoiding crowds, and washing hands with soap and running water. The results of this study concluded that the public knowledge factor has an important role in realizing the behavior of implementing health protocols. The higher the public's knowledge, the better their behavior in implementing health protocols.

Of the 10 questions in the questionnaire that measured the level of public knowledge, most of the respondents were able to answer correctly, which is related to what Covid-19 is, the nature of the Corona virus, how it is transmitted, and how to prevent transmission. People who have good knowledge are likely to have good attitudes and behavior. The knowledge of the people in Ngoro affects their behavior in preventing Covid-19 by implementing health protocols. Good knowledge can be supported by acceptance of information circulating in the community about Covid-19. Someone who already knows about certain information, then he will be able to determine and make decisions how he should deal with it.

In this study, it was found that most of the people had good knowledge about Covid-19, which was $96.8 \%$. This is also possible because the majority of respondents in the sample are high school graduates who have been able to absorb information related to Covid-19. Education requires humans to act and fill their lives in order to achieve safety and happiness. Education is needed to obtain information, for example things that support health so that it can improve the quality of life. Thus it can be interpreted that the higher a person's education, the easier it is to receive information so that the more knowledge they have, on the other hand, less education will hinder the development of one's attitude towards the values introduced (Priyoto, 2014). In addition, the ease with which people can access information from social media, internet, television, friends and neighbors, and health workers is a source of information for the community. Motivation affects one's knowledge, because it will increase curiosity about something, increasing curiosity will motivate someone to look for sources of information. The number of victims affected by Covid-19 increases the public's curiosity to access information. This is also a warning for the government to provide knowledge to the public about how to prevent Covid-19.

Hasil penelitian ini sesuai dengan penelitian yang dilakukan oleh Yehuda Imanuel Widyakusuma Putra, Novita Verayanti Manalu (2020) bahwa terdapat hubungan bermakna antara pengetahuan dengan perilaku masyarakat tentang Covid-19 di Kelurahan Batu Gantung, Nusaniwe, Kota Ambon. Pengetahuan yang baik dapat didukung oleh penerimaan terhadap informasi yang beredar di masyarakat tentang Covid 19. Seseorang yang telah mengetahui tentang suatu informasi tertentu, maka dia akan mampu menentukan dan mengambil keputusan bagaimana dia harus menghadapinya. Dengan kata lain, saat seseorang mempunyai informasi tentang Covid-19, maka ia akan mampu untuk menentukan bagaimana dirinya harus berperilaku terhadap Covid-19 tersebut (Ahmadi,2013)

The results of the analysis of the research data show that the attitude factor partially has a significant effect on the behavior of implementing health protocols to prevent Corona Virus Disease (Covid-19). Supported by the results of multiple regression statistical analysis, the t value is 16.525 with a significance level of $0.000(\mathrm{p}<0.05)$. These results can be interpreted that the attitude factor contributes significantly to the behavior of implementing health protocols.

Attitude is a form of evaluation or feeling reaction. A person's attitude towards an object is a feeling of support or favor (favorable) or feelings of not supporting or not taking sides (unfavorable) on the object (Azwar, 2011). Attitude is also a person's closed response to certain stimuli or objects that already involve the opinion and emotional factors concerned (happy-displeased, agree-disagree, good-bad, and so on). Attitude is a readiness or willingness to act, and not an implementation of a particular motive. In other words, the attitude function is not yet an action (open reaction) or activity, but rather a predisposition to behavior (action) or closed reactions. Health attitude is the opinion or judgment of people on matters relating to health care. Attitude towards health or a healthy attitude starts with oneself, by paying attention to the health needs in the body rather than desires. 
The results of the study also show that attitude is the dominant factor that has the strongest influence on the behavior of implementing health protocols. When a person already has the attitude and is committed to be willing to implement the health protocol, then he will carry out the behavior of implementing the health protocol. In other words, closed reactions are a predisposition to open reactions.

Based on the results of the research, $82.8 \%$ of the people have an attitude of willing to adopt health protocols such as wearing masks, maintaining distance and avoiding crowds, and washing their hands with soap and water. flows. The results of this study still show that there are still people who have an attitude that does not want to apply health protocols, namely $17.2 \%$ where among them are still not willing to remind others to apply health protocols.

\section{Analysis of The Relationship between Enabling Factors (Availability of Health Protocol Facilities) on The Behavior of The Implementation of Health Protocols in Prevention of Corona Virus Disease 2019 (Covid-19) in The Work Area of Ngoro Public Health Center Mojokerto Regency}

The results of the analysis of the research data show that the availability of health protocol facilities partially does not have a significant effect on the behavior of implementing health protocols to prevent Corona Virus Disease (Covid-19). This is supported by the statistical results of the test on the variable availability of health protocol facilities, the $t$ value is -0.930 with a significance level of 0.353 ( $p>0.05$ ). This result implies that the availability of health protocol facilities does not affect the behavior of implementing health protocols.

The results of this study indicate that the availability of health protocol facilities for implementing health protocols in the form of washing hands and soap, masks, and hands sanitizers does not guarantee the realization of the behavior of implementing health protocols. This shows that even though these facilities are widely available in public places and they also have their own, if there is no intention or awareness to implement health protocols then this behavior will also not materialize.

Most of the people have complete facilities and infrastructure, namely as much as $78.4 \%$, the rest have incomplete health protocol facilities and none of them stated that health protocol facilities are not available. This shows that each individual in the family and community has an awareness of providing these infrastructure. The availability of facilities and infrastructure which theoretically are enabling factors for behavior change, in this study did not show any influence on the behavior of implementing health protocols. This can be due to the availability of means or not, but if the community already has positive knowledge and attitudes towards the implementation of health behavior, then they will try to behave well. Most of the facilities that must be owned by the community are masks, a place for washing hands and soap, and a hand sanitizer. However, some of them do not have complete facilities, which are often not owned is a handsanitizer.

Lawrence Green's theory quoted by Soekidjo (2007: 178) states that one of the factors that determine the formation of a healthy lifestyle is the enabling factor, which is manifested in the physical environment, the available or unavailability of health facilities or facilities such as health centers, medicines. , contraceptives, latrines and so on. According to Lawrence Green, quoted by Soekidjo Notoatmodjo (2007: 179), the availability of facilities, attitudes and behavior of health workers towards health will also support and strengthen the formation of behavior. Enabling factors are antecedents of behavior that enable a motivation or aspiration to be fulfilled. A pregnant woman will find it easy to get health services if there are health workers, community health centers or hospitals available. Included in this factor is the availability of health resources in the form of health personnel, health facilities and infrastructure, skills, and affordability of health resources, all of which support or facilitate the occurrence of healthy behavior for a person or community. From the theoretical review, the availability of health protocol infrastructure can affect the behavior of implementing health protocols, but it could also not affect the results of this study. In this case, individuals, groups and communities are given the correct understanding of health. Then it is shown to them either directly or indirectly, namely through films, slides, photos, pictures, or stories, how dangerous is unhealthy behavior, and what is the benefit of having a healthy behavior. It is hoped that this will arouse their desire to have a healthy lifestyle. Furthermore, it has been repeatedly conveyed or shown to them that there have been more and more people who are behaving in a healthy manner 
and at the same time they have shown or conveyed the benefits, so that they will be moved to behave healthily.

\section{Analysis of The Relationship between Reinforcing Factor (Support) on The Behavior of The Implementation of Health Protocols in Prevention of Corona Virus Disease 2019 (Covid-19) in The Work Area of Ngoro Public Health Center Mojokerto Regency}

The results of the research data analysis show that the support factors partially have a significant effect on the behavior of implementing health protocols to prevent Corona Virus Disease (Covid-19). This is in accordance with the results of the $t$ test statistic on the support factor variable, the $t$ value is 5.524 with a significance level of $0.000(\mathrm{p}<0.05)$. This result means that the support factor is proven to significantly influence the behavior of implementing health protocols.

Reinforcing factors are factors that encourage or reinforce behavior. Sometimes, even though someone knows and is able to behave healthily, they don't. Reinforcing factors are factors that reinforce behavior, which are manifested in the attitudes and behavior of health workers, peers, parents, which are the reference group for community behavior.

Most of the community received strong support from families, the surrounding community, from across sectors and from the village government, amounting to $90.8 \%$ and none of them received no support at all. The cross tabulation between support and the behavior of implementing health protocols in Ngoro Public Health Center Mojokerto Regency shows that most people with good health protocol implementation behavior get strong support, namely 291 respondents $(92.09 \%)$ and the remaining 4 people $(12,50 \%)$ found weak support. Most of those who get weak support are due to the lack of support from the surrounding environment, namely from neighbors, where some of them have neighbors who do not want to wear masks and there is still leniency in crowd activities in their village environment such as moslem activities and tahlilan which do not require participants to wear face mask.

The existence of regulations to implement health protocols that are always intensely echoed in the surrounding environment, be it in places of worship, shops, and other public facilities can be able to strengthen the realization of the behavior of implementing health protocols. This is due to the fear of not being allowed to enter these public facilities or the possibility of a regulation which is a form of support to create a sense of security and encouragement to always apply health protocols. The results of the analysis which states that the reinforcing factor affects health behavior is in accordance with the theory which states that what causes a person to behave in a certain way is due to 4 main reasons, namely :

1. Thoughts and feelings, namely in the form of knowledge, perceptions, attitudes and judgments of a person towards an object (in this case, the object of health);

2. Important people as references. A person's behavior is more influenced by people who are considered important. If the person is important to him then what he says or does tends to be imitated;

3. Resources (resources). Resources here include facilities, money, time, energy and so on. All of this affects the behavior of a person or community group;

4. Normal behavior is one aspect of culture, then culture has a deep influence on this behavior. (Notoatmodjo, 2010).

The results of the research and linked to the theoretical review (number 2) indicate that the role of health workers and community leaders is very important to become role models or references for the community to want to apply health protocols. In accordance with the questions on the questionnaire that measures the support received by respondents, some important people who are considered as references are family, friends, groups, health workers, across sectors, central government regulations in implementing health protocols, local government regulations in implementing health protocols (village) as well as the surrounding environment. Furthermore, in health promotion there is a Precede-Proceed Model adapted from the Lawrence Green concept. This model examines the problem of human behavior and the factors that influence it, as well as how to follow it up by trying to change, maintain, or enhance this behavior in a more positive direction. The assessment process or at the precede stage and the follow-up process at the proceed stage. Thus a program for improving health behavior is the application of the four general processes to a model of assessment and follow-up. 
1. Quality of life is the main goal to be achieved in the field of development so that the quality of life is in line with the level of prosperity. The more prosperous, the higher the quality of life.

2. Health degree is something that is wanted to be achieved in the health sector, with the health degree it will illustrate the health problems that are being faced. The biggest influence is behavioral and environmental factors.

3. Environmental factors are physical, biological, and socio-cultural factors that directly / do not affect health status.

4. Behavioral and lifestyle factors are factors that arise because of the actions and reactions of a person or organism to their environment. Behavioral factors occur when there is stimulation, while lifestyle is a habit pattern of a person or group of people who are carried out because the type of work follows the trends that prevail in their peer group, or only to imitate their idol shop (Nursalam, 2016).

One of human nature is to want to imitate. Therefore, efforts are made to ensure that the public health center has a clean environment, the officers look clean, tidy and friendly. In addition, officers also behave in a healthy manner, for example not smoking, not spitting anywhere, not littering, and always applying health protocols in the era of the Covid-19 pandemic by always wearing masks, washing hands with soap and running water and keeping a distance. and stay away from the crowd. In some places, a place for washing hands with soap is provided so that people can always apply health protocols. With examples like this, usually people will do the same thing, namely behave healthily by implementing health protocols.

\section{Analysis of Dominant Factor in Behavior of The Implementation of Health Protocols in Prevention of Corona Virus Disease 2019 (Covid-19) in The Work Area of Ngoro Public Health Center Mojokerto Regency}

Overall, it is known that the factors of knowledge, attitude factors, availability of health protocol facilities and support factors simultaneously influence the behavior of implementing health protocols in the work area of Ngoro Public Health Center Mojokerto Regency. The analysis results obtained by the value of R Square (R2) of 0.664 . This shows that the behavior of implementing health protocols is influenced by knowledge factors, attitude factors, availability of health protocol facilities, as well as support factors of $66.4 \%$, while the remaining $33.6 \%$ is influenced by other factors not examined in this study.

From the results of the table of regression coefficient values, the results show that the highest coefficient value in the attitude variable is 0.637 , so the dominant variable / factor that affects the behavior of implementing health protocols in efforts to prevent Corona Virus Disease 2019 (Covid19 ) is an attitude variable.

Some of the questions in the questionnaire to measure attitudes are willingness to comply with government regulations related to the implementation of health protocols, willingness to adopt clean and healthy living habits (PHBS) wherever they are in order to prevent Covid-19 transmission, willingness to be responsible for safeguarding themselves from contracting Covid-19, willingness to implement health protocols (wash hands with soap, wear masks and keep your distance) and willingness to remind others to apply health protocols. Of the five questions, there were some respondents' attitudes that were still difficult to do, namely reminding others to apply health protocols, this was probably because there was a feeling of reluctance to be considered too patronizing and the person being reprimanded felt offended or displeased. But in general they are willing to implement health protocols on their own. From the cross tabulation table between the respondent's attitude and the behavior of implementing health protocols, it was found that most of the respondents who wanted to apply health protocols were 283 people $(98.26 \%)$ and those who did not want to apply health protocols but in the end had good behavior there were 12 people. (20.00\%). Meanwhile, 4 people had a willing attitude but the behavior was not good (1.39\%) and 1 person had bad behavior $(0.35 \%)$. This shows that the better a person's attitude towards implementing health protocol behavior, the more his actions will actually be the same.

Attitudes greatly influence the behavior of implementing health protocols. Society will take a certain action if he views the action positively and if he believes that other people want him to do it. In this case, the people in Ngoro Public Health Center area have the belief that the behavior of implementing the health protocol is positive and able to prevent the transmission of Covid-19 and this 
kind of behavior is what the people around / their surroundings really want and need. Appeals from the government have also strengthened his stance. This positive attitude is what drives the implementation of health protocols.

Some of the techniques that can be used to increase knowledge and change or strengthen attitudes are through outreach and discussions with community groups. So that the community feels involved in the process of behavior change, thereby forming attitudes that support behavior change, in this case the behavior of implementing health protocols.

\section{CONCLUSION}

1. The knowledge factor partially affects the behavior of implementing health protocols in an effort to prevent Corona Virus Disease (Covid-19) in the work area of Ngoro Public Health Center Mojokerto Regency.

2. Attitude factors partially affect the behavior of implementing health protocols in an effort to prevent Corona Virus Disease (Covid-19) in the work area of Ngoro Public Health Center Mojokerto Regency.

3. The availability of health protocol facilities partially does not affect the behavior of implementing health protocols in an effort to prevent Corona Virus Disease (Covid-19) in the work area of Ngoro Public Health Center Mojokerto Regency.

4. Support factors partially affect the behavior of implementing health protocols in an effort to prevent Corona Virus Disease (Covid-19) in the work area of Ngoro Public Health Center Mojokerto Regency.

5. Attitude factors are the dominant factors that influence the behavior of implementing health protocols in efforts to prevent Corona Virus Disease (Covid-19) in the work area of Ngoro Public Health Center Mojokerto Regency.

6. Knowledge factors, attitude factors, availability of health protocol facilities as well as support factors simultaneously influence the behavior of implementing health protocols in an effort to prevent Corona Virus Disease (Covid-19) in the work area of Ngoro Public Health Center Mojokerto Regency.

\section{ACKNOWLEDGMENTS}

We give the best gratitude to all staff of UPT Puskesmas Ngoro Mojokerto Regency. We also give the gratitude to all respondents who have been willing and participated on this study.

\section{CONFLICT OF INTEREST}

This study did not have any conflict of interest.

\section{REFERENCES}

Ahmadi (2013). Kesehatan Masyarakat, Teori dan Aplikasi. Jakarta: Raja Grafindo

Azwar, S. (2011). Sikap Manusia : Teori dan Pengukurannya. Yogyakarta : Pustaka Pelajar.

Keputusan Menteri Kesehatan Republik Indonesia Nomor Hk.01.07/Menkes/382/2020 Tentang Protokol Kesehatan Bagi Masyarakat di Tempat dan Fasilitas Umum dalam Rangka Pencegahan dan Pengendalian Corona Virus Disease 2019 (COVID-19)

Kementerian Kesehatan. (2020). Pedoman Pencegahan dan Pengendalian Coronavirus Disease (COVID-19). Jakarta : Kementerian Kesehatan.

Muhith, A., Nasir, A., Ideputri, M. E. (2011). Buku Ajar Metodologi Penelitian Kesehatan: Konsep pembuatan Karya Tulis dan Thesis untuk Mahasiswa Kesehatan. Yogyakarta: Nuha Medika.

Notoatmodjo, Soekidjo. (2003). Pendidikan Dan Perilaku Kesehatan. Jakarta : Rineka Cipta

Notoatmodjo, Soekidjo. (2010). Pendidikan Dan Perilaku Kesehatan. Jakarta : Rineka Cipta

Notoatmodjo, Soekidjo. (2012). Metodologi Penelitian Kesehatan. Jakarta: Rineka Cipta.

Nursalam. (2016). Metodologi Penelitian Ilmu Keperawatan. Jakarta : Salemba Medika.

Priyoto. (2014). Teori Sikap dan Perilaku dalam Kesehatan. Yogyakarta : Nuha Medika.

Rusmini, Hetti. Suryawan, Boby. (2014). Faktor-faktor Yang Mempengaruhi Sikap dan Perilaku Masyarakat Terhadap Kepatuhan Minum Obat Anti Filariasis di Kabupaten Bogor. Lampung : Universitas Malahayati. 
Sari, Devi Pramita. 'Atiqoh. Nabila Sholihah. (2020). Hubungan Antara Pengetahuan Masyarakat dengan Kepatuhan Penggunaan Masker sebagai Upaya Pencegahan Penyakit Covid-19 di Ngronggah. Surakarta : Universitas Duta Bangsa

Siswosudarmo, Risanto. (2015). Pendekatan Praktis Penelitian Epidemiologi Klinis \& Aplikasi SPSS untuk Analisis Statistika. Yogyakarta: Universitas Gajah Mada.

Sugiyono. (2014). Metode Penelitian Kuantitatif dan $R \&$ D. Jakarta : Alfabeta.

Taadi, Taadi. Setiyorini, Erni dan F. M. Rifqi. Amalya (2019). Faktor yang Berhubungan dengan Kepatuhan Cuci Tangan 6 Langkah Moment Pertama pada Keluarga Pasien di Ruang Anak. Blitar : Stikes Patria Husada.

Undang-Undang Republik Indonesia Nomor 20 Tahun 2003 tentang Sistem Pendidikan Nasional

Widyakusuma Putra,Yehuda Imanuel dan Manalu, Novita Verayanti. (2020). Tingkat Pengetahuan dengan Perilaku Warga Dalam Menjalankan Protokol Kesehatan di Masa New Normal Pandemi Corona. Ambon : Universitas Advent Indonesia 